\title{
Multi-Drug Resistant Acute Otitis Media amongst Children Attending Out-Patient Clinic in Chukwuemeka Odumegwu Ojukwu University Teaching Hospital, Awka, South-East Nigeria
}

\author{
Shedrack Obiora Ejiofor1, Amarachi Divine Edeh ${ }^{1,2}$, Chijioke Elias Ezeudu ${ }^{3}$, \\ Thaddeus Harrison Gugu2 ${ }^{2}$ Angus Nnamdi Oli2* \\ ${ }^{1}$ Department of Paeditrics, Chukwuemeka Odumegwu Ojukwu University Teaching Hospital, Awka, Nigeria \\ ${ }^{2}$ Department of Pharmaceutical Microbiology and Biotechnology, Faculty of Pharmaceutical Sciences, Nnamdi \\ Azikiwe University, Awka, Nigeria \\ ${ }^{3}$ Department of Paeditrics, College of Health Sciences, Nnamdi Azikiwe University, Nnewi Campus, Nnewi, Nigeria \\ Email: *a.n.oli@live.com
}

Received 17 May 2016; accepted 19 June 2016; published 22 June 2016

Copyright (C) 2016 by authors and Scientific Research Publishing Inc.

This work is licensed under the Creative Commons Attribution International License (CC BY). http://creativecommons.org/licenses/by/4.0/

(c) (i) Open Access

\section{Abstract}

Objective: The study assessed microbial etiology and multi-drug resistant profile of the pathogens isolated from children diagnosed of acute otitis media (AOM) at Chukwuemeka Odumegwu Ojukwu University Teaching Hospital, Awka. Method: Ear swab samples were collected aseptically from 40 children that visited the children out-patient clinic of the hospital. The samples were cultured within 20 minutes of collection and the isolates identified microbiologically. Antimicrobial susceptibility testing was done by Kirby-Bauer's disc diffusion method. Results: A total of 2025 children visited the hospital during the study period and $40(1.98 \%)$ had clinical diagnosis of acute otitis media. Ten (25\%) of the 40 samples did not yield any microbial growth. Children aged sone year had the highest prevalence of AOM (55\%). Staphylococcus aureus $(34.9 \%)$ was the predominant bacteria isolate followed by Pseudomonas aeruginosa (30.2\%) while Candida krusei (14\%) was the predominant fungi isolate. All the bacterial isolates were resistant to ampicillin and coamoxiclav. Staphylococcus aureus isolates were marginally susceptible to gentamicin $(60 \%)$ and sparfloxacin (73.3\%). Pseudomonas aeruginosa, Escherichia coli and Staphylococcus aureus were resistant to ceftriaxone, ciprofloxacin, streptomycin, cefuroxime, erythromycin and azithromycin. Nystatin and voriconazole had comparable effect $(60 \%)$ against the fungal isolates and flucona-

\footnotetext{
${ }^{*}$ Corresponding author.
}

How to cite this paper: Ejiofor, S.O., Edeh, A.D., Ezeudu, C.E., Gugu, T.H. and Oli, A.N. (2016) Multi-Drug Resistant Acute Otitis Media amongst Children Attending Out-Patient Clinic in Chukwuemeka Odumegwu Ojukwu University Teaching Hospital, Awka, South-East Nigeria. Advances in Microbiology, 6, 495-501. http://dx.doi.org/10.4236/aim.2016.67049 
zole was ineffective. Conclusion: The incidence of multiple antibiotic resistant bacteria associated with acute otitis media in the pediatric patient was very high. Empiric treatment of the infection in the community should be discouraged. AOM preventive strategies should be targeted on the very young children to reduce the risk of recurrence.

\title{
Keywords
}

\author{
Acute Otitis Media, Antimicrobial Resistance, Tertiary Health Institution, Peadiatric Infection, \\ Low-Income Country
}

\section{Introduction}

Otitis media in children accounts for great number of visits to peadiatric infection clinics globally and especially in many developing countries [1] [2]. It is worsened by increase in day-care centres outside the home and unhygienic environments [3]. Acute otitis media is most common among children between the ages of three months and three years with a peak incidence between 6 and 9 months [1]. By one year of age, at least $60 \%$ of children have experienced an episode and 17\% have suffered at least 3 episodes of AOM [4]. It is an inflammation of the middle ear usually caused by bacteria, but sometimes by fungi, virus, Mycoplasma pneumoniae and Chlamydia trachomatis [5]. Otitis media is characterized by fluid build up behind the ear drum and occurs in area between the tympanic membrane and the inner ear, including the duct called Eustachian tube [6]. Children are more affected by acute otitis media than adults because their Eustachian tubes are shorter and more horizontal and their immune functions are not yet fully developed to resist pathogens [7] [8]. Otitis media has been classified into three main types such as Acute Otitis media (AOM), Otitis media with effusion (OME) and chronic Otitis media with effusion (COME) [9].

Otitis media is prevalent among Nigerian children and it is found to occur more in children of mothers with lower educational status and in children sleeping more than 4 in the same room [2]. In a study carried out in Ilesha, Osun state of Nigeria over one year period from 2004 to 2005, the prevalent of AOM was 1.01\% [10].

Drug resistant is a common phenomenon among children with infectious disease in our environment ownig to irrational use of antimicrobial agents. This study therefore, assessed the microbial etiology and multi-drug resistant profile of the pathogens isolated from children diagnosed of acute otitis media in the children's outpatient clinics of Chukwuemeka Odumegwu Ojukwu University Teaching Hospital (COOUTH), Awka. The hospital serves as a referral center to a lot of surrounding village communities of over 2 million persons.

\section{Methodology}

\subsection{Study Population/Center}

The study was done at COOUTH Awka, which is a tertiary Health centre located at Awka, the capital of Anambra State. It is a 150 bedded Hospital established in 2011 to train medical personnel and cater for the health needs of surrounding communities of over 2 million population. The study population comprised children aged one month to 9 years, who presented at the paediatric out-patient clinic of the hospital from January to April 2015. Participants were recruited consecutively after a verbal informed consent was obtained from their legal care givers.

\subsection{Samples Collection}

Recruitment of study participants and sample collection were done by the paediatrician. Diagnosis was based on clinical manifestation of acute otitis media on the children attending the paediatric out-patient clinic of the hospital. Forty samples of ear swab were collected using sterile swab sticks and were labeled for age and sex of patients.

\subsection{Ethical Considerations}

The study was explained to the parents of the children and a verbal consent was obtained from them. The study 
protocol was approved (Approval number: ANSUTH/AA/VOL.XI/004) by the ethics committee of COOUTH, Awka.

\subsection{Isolation and Identification of Organisms and Antibiogram Study}

The swab sticks used for the collection of the samples were streaked directly on well labeled MacConkey, mannitol salt, cetrimide and chocolate blood agar, incubated at $37^{\circ} \mathrm{C}$ for $24 \mathrm{~h}$ to enable for bacteria isolation. After incubation, cultures were examined for significant growth. Subcultures were prepared in nutrient agar plates, and incubated for another $24 \mathrm{~h}$. Grams staining and Biochemical test (Indole production, Oxidase, catalase and Coagulase) was carried out in accordance with standard methods [11]. To enable for fungal isolation and identification, the swab sticks were streaked directly on the well-labeled Sabouraud Dextrose Agar (SDA) plates and incubated at room temperature for 48 hours. Each fungal growth was identified based on their morphological and cultural characteristics. All yeast isolates were identified with CHROMagar. The Antimicrobial susceptibility testing was done by Kirby-Bauer's disc diffusion method and interpretation was in according with European Committee on Antimicrobial Susceptibility Testing (EUCAST) guidelines (http://www.eucast.org) for these drugs: azithromycin, erythromycin, ciprofloxacin, sparfloxacin, gentamicin, streptomycin, ceftriaxone, cefuroxime, ampicillin, co-amoxiclav, nystatin, fluconazole and voriconazole.

\subsection{Data Analysis}

This was done using Graphpad Prism Version 5.0 statistical package. Tests of significance were done using One-way analysis of variance, Chi-square test and Mann Whitney test and P-value of $<0.05$ was considered significant. Results were presented in tables.

\section{Results}

Out of 2025 children who attended the children's out-patient clinic during the period, 40 of them were diagnosed of having acute otitis media giving an incidence rate of 1.98\%. Their ages ranged from 1 month to 9 years comprising 25 males and 15 females with male-female ratio of 1.67:1 (Table 1). AOM was significantly more prevalent in males than in females $(\mathrm{P}<0.05)$. The age group $\leq 1$ year were most affected, having about half the total number the AOM patient.

Table 2 depicts the different causative organisms isolated. Thirty (75\%) out of the 40 samples collected were culture positive, while the remaining ten yielded no organism. Thirty three bacteria isolates were recovered in the study with Staphylococcus aureus (34.9\%) being the predominant isolate followed by Pseudomonas aeruginosa (30.2\%). These were not statistically significant $\mathrm{P}>0.05$. A total of 10 fungi isolates were obtained as shown in Table 2 with Candida krusei accounting for the highest (14\%) of AOM of Candida aetiology while Candida glabrata and other Candida spp. were equal in occurrence (4.7\%). Mann Whitney test of significance showed that bacteria, although more commonly isolated in the study, are not significantly the more common etiology than fungi $(\mathrm{P}>0.05)$. Out of the 40 samples collected, 30 (66.67\%) yielded positive single microbial cultures while 10 (33.3\%) had mixed microbial growth.

Table 3 shows the resistance profile of the isolates. The most promising drug for the management of AOM of bacterial origin in these patients appears to be ciprofloxacin, a drug not commonly recommended for use in

\begin{tabular}{ccccc}
\multicolumn{5}{l}{ Table 1. Age and sex distribution of patients. } \\
\hline Age (years) & Males & Females & Total & \% Total \\
\hline$\leq 1$ & 18 & 4 & 22 & 55 \\
$2-4$ & 1 & 7 & 8 & 20 \\
$5-7$ & 1 & 4 & 5 & 12.5 \\
$8-9$ & 5 & 0 & 5 & 12.5 \\
Total & 25 & 15 & 40 & 100.0 \\
\hline
\end{tabular}

P value $=0.0003$ (Chi square test). 
Table 2. A profile of the isolates.

\begin{tabular}{cccc}
\hline Bacteria & Number (\%) & Fungi & Number (\%) \\
\hline Staphylococcus aureus & $15(34.9)$ & Candida glabrata & $2(4.7)$ \\
Pseudomonas aeruginosa & $13(30.2)$ & Candida krusei & $6(14)$ \\
Escherichia coli & $4(9.3)$ & Other Candida spp. & $2(4.7)$ \\
Streptococcus spp. & $1(2.3)$ & Total & $10(23.4)$ \\
Total & $33(76.7)$ & & \\
\hline
\end{tabular}

P value $=0.6286$ (Mann Whitney test: Two-tailed).

children, followed by gentamicin. They demonstrated the least resistance profile. On the other hand, the $\beta$-lactamase antibiotics were totally useless having a resistance profile range of $90.91 \%$ - 100\% (Table 3(a)).

Out of the three antifungal agents tested, voriconazole and nystatin had comparable result (Table 3(b)) while fluconazole was not very effective. One-way analysis of variance $\mathrm{P}$ value $=0.8503$. There was, therefore, no significant difference in the effectiveness of the three agents.

The incidence of multi-drug resistant isolates (Table 3(c)) was calculated as

The incidence of multi-drug resistant isolates

$=\frac{\text { Number of isolates with MARI }>20 \%}{\text { Total number of Isolates }} \times 100=33 / 33 * 100=100 \%$.

\subsection{Abbreviations and Acronyms}

AOM = Acute otitis media.

EUCAST $=$ European Committee on Antimicrobial Susceptibility Testing.

COOUTH = Chukwuemeka Odimegwu Ojukwu University Teaching Hospital.

OME = Otitis media with effusion .

COME= Chronic Otitis media with effusion.

\subsection{Equations}

The incidence of multi-drug resistant isolates $=\frac{\text { Number of isolates with MARI }>20 \%}{\text { Total number of Isolates }} \times 100$

\section{Discussion}

This study showed that children $\leq 1$ year were most prone to AOM as they had the highest incidence rate (55\%). This is age most prone to day-care outside the home. The finding corresponds with some previous studies [8] [12]. Other workers inside and outside Nigeria had also reported high incidence of AOM in day-care centers [3] [9]. Children, generally, are more predisposed to having more incidence of AOM than the adults. This is attributed to their having shorter and more horizontal Eustachian tube, lower immunity compared to adults and the fact that bacteria adhere better to epithelial cells of young children than adults [7]. The males had a significantly $(\mathrm{P}<0.05)$ higher prevalence than females and this consistent with reports of Nwankwo and Okeke [13] and Wang et al. [14]. The reason for this observation is still unknown.

The present study showed that Staphylococcus aureus were the predominant isolate causing acute otitis media followed by Pseudomonas aeruginosa. All the identified bacterial isolates correspond to similar study done by Nwankwo and Okeke [13] who also reported the preponderance of S. aureus. In contrast however Osazuwa et al. [12] and Ogbogu et al. [15] reported Pseudomonas aeruginosa as the most frequent isolate of otitis media followed by S. aureus and Proteus spp. In developed countries, the commonest bacterial pathogens of acute otitis media were S. pneumoniae, H. influenzaeand M. catarrhalis [3] [5] [16]. Possible reasons for the difference in isolated organisms might be related to the effect of climate and pattern of antibiotic use. The remaining 10 samples 
Table 3. Resistance profile of the isolates to conventional antimicrobials.

(a)

\begin{tabular}{ccccccc}
\hline & \multicolumn{5}{c}{ Antibacterial agents } \\
\hline S/N & Antibiotics & \multicolumn{5}{c}{ Number of the isolates resistance to commercial antibiotics (\%) } \\
\cline { 3 - 7 } & & $\begin{array}{c}\text { P. aeruginosa } \\
\mathrm{N}=13\end{array}$ & $\begin{array}{c}\text { E. coli } \\
\mathrm{N}=4\end{array}$ & $\begin{array}{c}\text { Streptococcus spp. } \\
\mathrm{N}=1\end{array}$ & $\begin{array}{c}\text { S. aureus } \\
\mathrm{N}=15\end{array}$ & Total \\
$\mathrm{N}=33$ \\
\hline 1 & Azithromycin & $13(100)$ & $0(0)$ & $1(100)$ & $15(100)$ & $29(87.88)$ \\
2 & Erythromycin & $13(100)$ & $0(0)$ & $1(100)$ & $13(86.7)$ & $27(81.82)$ \\
3 & Ciprofloxacin & $6(46.15)$ & $2(50)$ & $0(0)$ & $7(46.7)$ & $15(45.45)$ \\
4 & Sparfloxacin & $12(92.3)$ & $3(75)$ & $0(0)$ & $4(26.7)$ & $19(57.58)$ \\
5 & Gentamicin & $5(38.5)$ & $4(100)$ & $1(100)$ & $6(40)$ & $16(48.48)$ \\
6 & Streptomycin & $12(92.3)$ & $3(75)$ & $1(100)$ & $15(100)$ & $31(93.94)$ \\
7 & Ceftriaxone & $12(92.3)$ & $4(100)$ & $1(100)$ & $13(87.7)$ & $30(90.91)$ \\
8 & Cefuroxime & $13(100)$ & $4(100)$ & $1(100)$ & $12(80)$ & $30(90.91)$ \\
9 & Ampicillin & $13(100)$ & $4(100)$ & $1(100)$ & $15(100)$ & $33(100)$ \\
10 & Co-amoxiclav & $13(100)$ & $4(100)$ & $1(100)$ & $15(100)$ & $33(100)$ \\
\hline
\end{tabular}

(b)

\begin{tabular}{|c|c|c|c|c|c|}
\hline \multicolumn{6}{|c|}{ Antifungal agents } \\
\hline \multirow[b]{2}{*}{$\mathrm{S} / \mathrm{N}$} & \multirow[b]{2}{*}{ Antifungal agent } & \multicolumn{4}{|c|}{ Number of the isolates resistance to commercial antifungal agents (\%) } \\
\hline & & $\begin{array}{l}\text { Candida glabrata } \\
\qquad \mathrm{N}=2\end{array}$ & $\begin{array}{l}\text { Candida krusei } \\
\quad \mathrm{N}=6\end{array}$ & $\begin{array}{l}\text { Other Candida spp. } \\
\qquad \mathrm{N}=2\end{array}$ & $\begin{array}{c}\text { Total } \\
\mathrm{N}=10\end{array}$ \\
\hline 1 & Nystatin & $2(100)$ & $0(0)$ & $2(100)$ & $4(40)$ \\
\hline 2 & Fluconazole & $2(100)$ & $2(33.33)$ & $2(100)$ & $6(60)$ \\
\hline 3 & Voriconazole & $1(50)$ & $2(33.33)$ & $1(50)$ & $4(40)$ \\
\hline
\end{tabular}

(c)

\begin{tabular}{|c|c|c|c|c|c|}
\hline \multicolumn{6}{|c|}{ Multi-Antibiotics Resistance Index (MARI) analysis of the bacterial isolates } \\
\hline $\mathrm{S} / \mathrm{N}$ & $\begin{array}{l}\text { Bacterial } \\
\text { Isolates }\end{array}$ & $\begin{array}{l}\text { Number of } \\
\text { Isolates }\end{array}$ & $\begin{array}{l}\text { Number of isolates } \\
\text { resistant to } \geq 3 \\
\text { antibiotics }\end{array}$ & $\begin{array}{l}\text { Number of antibiotics } \\
\text { to which the isolates } \\
\text { were resistant (a) }\end{array}$ & MARI $(\mathrm{a} / \mathrm{b})$ in \% \\
\hline 1 & P. aeruginosa & 13 & 13 & 10 & 100 \\
\hline 2 & E. coli & 4 & 4 & 8 & 80 \\
\hline 3 & Streptococcus spp. & 1 & 1 & 8 & 100 \\
\hline \multirow[t]{2}{*}{4} & S. aureus & 15 & 15 & 10 & 80 \\
\hline & Total & 33 & 33 & & \\
\hline
\end{tabular}

that were culture negative, suggested that the parents or caregiver may have given some antibiotics to these children before presenting to the hospital, and this could have inhibited the growth of the pathogens.

This study showed that mixed microbial infection are less than single microbial infection which correlates and correspond to similar study carried out in India by Saraswati et al. [17]. Candida krusei and C. glabrata were the commonest fungal organisms isolated in this study and contrasted with previous study done in Benin City by Ogbogu et al. [15] which isolated C. albicans. Possible reasons for this observation may be related to environment influence. 
The isolates showed a high level of multi-antibiotic resistance (100\%). This corresponds with similar study carried out at by Nwankwo and Okeke [13] at Umuahia, Abia State of Nigeria. This might be due to misuse of the antibiotic and if not corrected may lead to loss of the drug efficacy in treating infections. The only Streptococcus spp isolated in the present study did not show any resistance to ciprofloxacin. This corresponds to the report in similar study by Nwankwo and Okeke [13] where 1 out of 8 isolates of Streptococcus were resistant to ciprofloxacin. In consonant with our study, Pseudomonas spp. had been shown to be resistant to ciprofloxacin [18]. Similar drug resistant pattern was also observed on cefuroxime and other beta-lactam antibiotics when used against Escherichia coli, Pseudomonas aeruginosa and Streptococcus species [18]. The resistance of Staphylococcus and Streptococcus to sparfloxacin, although low in our study (26.7\% and $0 \%$ respectively) and of Pseudomonas and E. coli, observed to be high, (92.3\% and 75\% resistance respectively) could be due to point mutation in the DNA gyrase of the bacteria leading to the loss of the organisms binding affinity to the drugs, hence loss of activity [19].

The resistance profile of the fungal isolate to different antifungal agents (nystatin, fluconazole and voriconazole) used in this study is a serious concern. This could be as a result of misuse of fluconazole in the environment and increased use in the management of HIV infection. The drug, although a prescription—only medicine is often purchased by patients without prescription. Similar report exists in the northern part of the country [20] and calls for the speedy implementation of the policy on rational drug use in the country.

\section{Conclusion}

The incidence of multiple antibiotic resistant bacteria associated with acute otitis media in the paediatric patient was unacceptably very high. Empirical treatment of the infection in the community should be discouraged. Instead thorough microbiological investigations should be done before commencement of treatment to avoid treatment failure and spread of resistant organisms. AOM preventive strategies should be targeted on the male and very young children to reduce the risk of recurrence.

\section{Acknowledgements}

Authors wish to acknowledge the management of COOUTH, Amaku, Awka for granting us permission to conduct the study. We also wish to thank the guardians and parents of the children that participated in the study.

\section{Funding}

The study was fully self-funded. No fund was received by any donor agent.

\section{References}

[1] Daly, K.A., Brown, J.E., Lindgren, B.R., Meland, M.H., Le, C.T. and Glebink, G.S. (1999) Epidemiology of Otitis Media Onset by Six Months of Age. Pediatrics, 103, 1158-1166. http://dx.doi.org/10.1542/peds.103.6.1158

[2] Amusa, Y.B., Ijadunola, I.K.T. and Onayade, O.O. (2005) Epidemiology of Otitis Media in a Local Tropical African Population. West African Journal of Medicine, 24, 227-230.

[3] Greenberg, D., Hoffman, S., Leibovitz, E. and Dagan, R. (2008) Acute Otitis Media in Children: Association with Day Care Centers-Antibacterial Resistance, Treatment, and Prevention. Paediatric Drugs, 10, 75-83. http://dx.doi.org/10.2165/00148581-200810020-00002

[4] Faden, H., Duffy, L. and Boeve, M. (1998) Otitis Media: Back to Basics. Peadiatric Infectious Disease Journal, 17, 105-112. http://dx.doi.org/10.1097/00006454-199812000-00002

[5] Bock, S.L. (1997) Causative Pathogens, Antibiotic Resistance and Therapeutic Considerations in Otitis Media. Infectious Disease Journal, 16, 449-456. http://dx.doi.org/10.1097/00006454-199704000-00029

[6] Jido, B.A., Yahaya, A. and Yadock, L.H. (2014) Isolation and Antimicrobial Susceptibility Pattern of Pseudomonas aeruginosa in Cases of Otitis Media among Patients Attending Ahmadu Bello University Teaching Hospital, Zaria, Nigeria. European Journal of Biotechnology and Bioscience, 2, 18-23.

[7] Pelton, S. (1996) New Concepts in the Pathophysiology and Management of Middle Ear Disease in Children. Drugs, 52, 62-67. http://dx.doi.org/10.2165/00003495-199600522-00013

[8] Weiner, R. and Collison, P.J. (2003) Middle Ear Pathogens in Otitis Prone Children. South Dakota Journal of Medicine, 56, 103-107. 
[9] Lain, M.K., Tahtinen, P.A., Runskanen, O., Huovinen, P. and Ruohola, A. (2010) Symptoms or Symptom Based Scores Cannot Predict Acute Otitis Media at Otitis Prone Age. Pediatrics, 125, 1154-1161. http://dx.doi.org/10.1542/peds.2009-2689

[10] Olubanjo, O. (2007) Epidemiology of Acute Suppurative Otitis Media in Nigerian Children. Internet Journal of Pediatrics and Neonatology, 8.

[11] Monica, C. (2006) District Laboratory Practice in Tropical Countries Part 2. 2nd Edition, Cambridge University Press, Cambridge.

[12] Osazuwa, F., Osazuwa, E., Osimee, C., Igharo, E.A., Imade, P.E., Lofor, P., Momoh, M., Omoregie, R. and Dirisy, J. (2011) Etiologic Agents of Otitis Media in Benin City, Nigeria. North American Journal of Medical Sciences, 3, 95-98. http://dx.doi.org/10.4297/najms.2011.395

[13] Nwankwo, I.U. and Okeke, O.H. (2014) Antibiogram of Bacteria Pathogens Associated with Otitis Media at Federal Medical Centre Umuahia, Nigeria. Journal of Microbiology Research, 2, 32-36.

[14] Wang, P.-C., Chang, Y.-H., Chuang, L.-J., Su, H.-F. and Li, C.-Y. (2011) Incidence and Recurrence of Acute Otitis Media in Taiwan's Pediatric Population. Clinics, 66, 395-399. http://doi.org/10.1590/S1807-59322011000300005

[15] Ogbogu, P.I., Eghafora, N.O. and Ogbogu, M.I. (2013) Microbiology of Otitis Media among Children Attending a Tertiary Hospital in Benin-City, Nigeria. Journal of Public Health and Epidemiology, 5, 280-284.

[16] Jacobs, M.R., Dagan, R., Appalbaum, P.C. and Burch, D.J. (1998) Prevalence of Antimicrobial Resistant Pathogens in Middle Ear Fluid; Multinational Study of 917 Children with Acute Otitis Media. Antimicrobial Agents and Chemotherapy, 42, 589-595.

[17] Saraswati, R., Venkatesh, R. and Jeya, M. (2013) Study of Aerobic Bacterial and Fungal Etiology of Chronic Supportive Otitis Media in Tertiary Care Hospital in Outskirts of Chennai India. International Journal of Research in Health Sciences, 1, 199-203.

[18] Imane, E., Rachid, M., Maamar, Y. and Mimoun, Z. (2014) Isolation and Antibiotic Susceptibility of Bacteria from Otitis Media Infections in Children in Rabat, Morocco. Journal of Biology, Agriculture and Health Care, 4.

[19] Redgrave, L.S., Sutton, S.B., Webber, M.A. and Piddock, L.J.V. (2014) Fluoroquinolone Resistance: Mechanisms, Impact on Bacteria, and Role in Evolutionary Success. Trends in Microbiology, 22, 438-445. http://dx.doi.org/10.1016/j.tim.2014.04.007

[20] Bello, R.H., Agbo, E.B. and Olabode, H.O.K. (2011) Antibiogram of Bacterial and Fungal Isolates Associated with Otitis Media amongst Children in Bauchi State, Nigeria. International Journal of Pharmacy and Bioscience, 2, 200207.

\section{Submit or recommend next manuscript to SCIRP and we will provide best service for you:}

Accepting pre-submission inquiries through Email, Facebook, Linkedin, Twitter, etc A wide selection of journals (inclusive of 9 subjects, more than 200 journals)

Providing a 24-hour high-quality service

User-friendly online submission system

Fair and swift peer-review system

Efficient typesetting and proofreading procedure

Display of the result of downloads and visits, as well as the number of cited articles

Maximum dissemination of your research work

Submit your manuscript at: http://papersubmission.scirp.org/ 